\title{
Nehemiah Fundraising Strategy: A Model for the Ghanaian Church
}

\author{
Iddrissu Adam Shaibu ${ }^{1}$ \\ ${ }^{1}$ Department of Religion and Human Values, College of Humanities and Legal Studies, University of Cape Coast, Cape Coast- Ghana.
}

\begin{abstract}
Even though fundraising has been part of the religious practices of the Church since its inception, its development over the centuries has led to the adoption of several fundraising strategies, which has led to overdependence on the congregation as the main source of funding. This situation has created fatigue in giving among a section of the congregation and its attendant complaints. Consequently, calls have been made for the Church in Ghana to wean itself from the traditional sources of generating funds and look for alternative sources of funding its activities. It is against this backdrop that this paper provides an alternative mean that the Church can use to wean itself from the traditional system of generating funds and thus be receptive to a more sustainable system of funds generation, which is the Nehemiah fundraising model. This research was done through primary and secondary sources and it became known that the adoption of Nehemiah's fundraising model must be guided by certain principles. The application of Nehemiah's model would aid the Church not only generate funds to meet its ever-increasing demands, but it would also reduce, to some extent, the Church's dependence syndrome on the traditional system.
\end{abstract}

Keywords: Fundraising, Model, Traditional Fundraising system, Church and Strategies

Correspondence:

Iddrissu Shaibu Adam

Email: isadam@ucc.edu.gh

Publication History

Received 17th December, 2020,

Accepted 19 January, 2021,

Published online 4th February, 2021.

(C) 2021 The Author(s). Published and Maintained by Noyam Publishers.

This is an open access article under the CCBY license (http://creativecommons.org/licenses/by/4.0/).

\section{INTRODUCTION}

It is appropriate to commence by defining the context in which certain terms are used in this study. Fundraising is one term that has been defined by scholars such as Kathleen S. Kelly, Kent R. Wilson, Alan R. Andreasen and Phillip Kotler among others. ${ }^{1}$ Nevertheless, in this study, the term refers to the process the Church uses to solicit resources from both adherents and occasionally, from non-adherents for its establishment, maintenance, sustenance, and growth. This includes strategies such as offerings, tithe, fundraising, donations and dues or levies. Nevertheless, the Traditional Fundraising System is used in the study to refer to the mode of soliciting funds from the congregation, which was inherited from the early church and was part of the liturgy of the Church when it was introduced in Ghana. The "normal offering' and tithe was initially introduced into the Ghanaian Church when it became autonomous and since then other forms of raising funds have been introduced into the Church. ${ }^{2}$

Since the establishment of the Church in Ghana, then Gold Coast, the Ghanaian Church has depended on the traditional system of soliciting funds from the congregation. One would have thought that after all these years the Church would have been receptive to new ideas. Yet, even in this twenty-first century, when the Ghanaian Church has become sophisticated, it is still depending mainly on the traditional system. What is more, the growing sophistication of the Church has led to the proliferation of the liturgical practice of the Church and one area that has experienced the effect of the modifications is the strategy of fundraising. The modification has witnessed the introduction and adoption of various fundraising strategies, such as appeal for funds, product selling, transportation offering, spirit offering and

\footnotetext{
Kathleen S. Kelly, Effective Fund- Raising Management, (Mahwah, NJ: Erlbaum, 1988), 6; Kent R. Wilson, Stewards leadership: Characteristics of the steward leader in Christian non-profit organisations. (Scotland: University of Aberdeen, 2010), 15: Alan R. Andreasen and Philip Kotler, Strategic Marketing for Nonprofit Organizations, (Upper Saddle River, New Jersey: Prentice Hall, 2008), 26.

2 Iddrissu A. Shaibu, 'Approaches to Church Fundraising and their Implications for Christians in Ghana: Case studies of selected Churches in Cape Coast", An unpublished Master of Philosophy thesis submitted to the Department of Religion and Human Values, University of Cape Coast, 2010.
} 
harvest among others. One may argue that the various strategies are to aid the Church to meet its ever-increasing financial demands. ${ }^{3}$ Nevertheless, the application of the various strategies had received an unfavourable response from a section of the Church. ${ }^{4}$ Perhaps, it is in sharing the sentiment of the perturbed Christians, that Rt. Rev. Prof. Emmanuel Martey, former Presbyterian Church of Ghana Moderator, in 2010, called on the Ghanaian Church to wean itself from the overdependence on offerings and tithes. He thinks that such practices have created fatigue in giving among Christians. ${ }^{5}$ In 2014, Otumfuo Osei Tutu II, the Chief of the Asante kingdom, also called on the Ghanaian Church to wean itself from the traditional sources of generating funds and be receptive to new ideas. ${ }^{6}$

These calls are timely, considering the complaints that are emerging from some Christians regarding the various fundraising strategies that are currently used by churches to generate funds from their congregants. This in a way goes to burden the congregation who are compelled to give amid the economic volatility and global unrest that they find themselves. Besides, depending on one source is not healthy in that the collapse or otherwise of that source could spell doom or lead to some operational difficulties for the Church. It is against this backdrop that this study seeks to present Nehemiah's fundraising strategy as a viable alternative source of generating funds that the Ghanaian Church can adopt to raise funds to minimize, if not to eliminate, the fatigue that has arisen regarding giving.

\section{Nehemiah's Strategies}

Nehemiah's strategy included personal prayer, an appeal to a major donor, a request for a government grant, executive planning, pivotal leadership meetings, use of volunteers, debt counselling (sic) and action to reduce debt, reductions in executive salaries and encouragement of personal gifts by the heads of families, as well as gifts by leaders and the general public. ${ }^{7}$

Although the context regarding Nehemiah's fundraising is different from the present Ghanaian context to some extent, and since historical events have parallels, from which lessons can be drawn, not all the above strategies may be relevant or applicable for the Church. In this regard, the Church can use relevant strategies to aid its fundraising activities.

\section{The Effective Application of the Nehemiah Fundraising Strategy to the Ghanaian Church.}

Studying Nehemiah's fundraising would enable the Church to wean itself from the traditional fundraising system. Nehemiah's fundraising stewardship drive has been adopted by churches in the United States of America. ${ }^{8}$ Klein argues that churches in the United States of America have a stewardship drive where they visit non-members soliciting funds. The churches usually ask non-members to pledge whatever amount they can and when they think, their pledges could be redeemed by the church. From her account, churches that have adopted this drive are making headways. ${ }^{9}$ In other words, Klein opines that churches in America have diversified their sources of funding to survive in a competitive global world. ${ }^{10}$ Similarly, the Ghanaian Church can also diversify its sources of funding to meet its evangelism and mission obligations as well as other obligations should it adopt this model of Nehemiah.

To adopt the Nehemiah fundraising model, the Church has to be guided by certain principles and these are; God owns everything, relationship building, and work with people and wrestling wisely.

It is worth stating from the onset that Nehemiah's fundraising theology is derived from the theology of the Psalmist; that is Psalms 24: 1 and 89: 11. The passages claim that the earth is the Lord's and the fullness thereof, the world and those who dwell therein (RSV) - The psalmist declares God's dominion over this world in general, and his providential presence in every part of it. To the Israelites as well as Christians, God owns the universe and everything in it and this is what guides Nehemiah's fundraising theology. If God owns all things by virtue of creation, it implies that whatever man possesses, he/she does so as a steward. Knowing that God is the Creator, Sustainer and Owner should make the Church feel at ease in soliciting funds from the congregation and non-members as well.

Aside from this acknowledgment, the Church needs to think of relationship building, which is also significant in fundraising. In fundraising, relationship building is paramount to the success or otherwise of the fundraising and

\footnotetext{
Shaibu, "Approaches to Church Fundraising and their Implications for Christians in Ghana"; Ghanaian Times, 'Presby Moderator: Church offerings are too much' 8 August 2010. Accessed 15 May 2020. https:/www.modernghana.com/news/288574/presby-moderator-church-offerings-are-too-much.html.

Kim Klein, Fundraising for Social Change. (San Francisco: Jossey-Bass (2007), 12.

News Ghana. 'Local churches told to wean itself from the traditional sources of generating funds'. Mar 9, 2014. Accessed on 15 May 2020. https://newsghana.com.gh/local-churches-told-to-wean-itself-from-the-traditional-sources-of-generating-funds/

News Ghana. 'Local churches told to wean itself from the traditional sources of generating funds'

Samuel Waje, Kunhiyop, African Christian Ethics. (Nairobi: Hippo Books, 2008), 177.

Kim Klein, Fundraising for Social Change. (San Francisco: Jossey-Bass (2007), 12.

Klein, Fundraising for Social Change, 12.

Klein, Fundraising for Social Change, 12.
} 
Burnett and Burk have reiterated this. ${ }^{11}$ Relationship in this regard is not just about raising funds, it is as Burnett, opines, "an approach to the marketing of a cause that centers on a unique and special relationship between a non-profit (the Church) and each support. Its overriding consideration is to care for and develop that bond and to do nothing that might damage or jeopardize it. Every activity is therefore geared toward making sure donors know they are important, valued, and considered, which has the effect of maximizing funds per donor in the long term"12

In light of this assertion, professional fundraisers and non-profit organisations are vigorously upgrading their transactions between donors and non-profit organisations. The act of upgrading their transaction orientation is a step in the right direction; nonetheless, it would be better, as Burnett asserts for the two parties to 'move away' from a transaction orientation to a relationship orientation. In this regard, the relationship in fundraising is a return to the intimacy of the one-to-one relationship between donors (congregants) and non-profit organisations (Church). ${ }^{13}$ The relationship orientation is also seen in the Nehemiah fundraising strategy and it is in two levels, vertical and horizontal. The vertical perspective deals with nurturing a relationship with God and the horizontal perspective focuses on nurturing a relationship with fellow humans.

\section{The Vertical Relationship}

In the vertical relationship, one has to wait upon the Lord, which is paramount in every aspect of one's life. For instance, Nehemiah, after receiving the bad news regarding the happenings in Jerusalem (Neh. 1:2-) waited upon the Lord for guidance. During the waiting period, he mourned, fasted and prayed to God for direction regarding the issue at hand (1: 5-11). Similarly, before embarking on any fundraising activity, it is significant that the Church always seeks God's face. Individual believers can also take a clue from this relationship-building when they are confronted with life challenges to seek God first.

After seeking God's face for four months, God presented Nehemiah with the opportunity to meet the King. This does not mean that during the waiting period Nehemiah was not playing his role as a cupbearer to the King, he did perform his functions and hence met the King every day. He was waiting for God's designated time to tell the King his concern. It is worth noting that when the right time came Nehemiah still prayed to God for wisdom and direction on how to place his request before the King. Nehemiah's act points to the fact that he depended on God in whatever he did. Because he depended on God, his prayer yielded a positive result in that the King granted his request (Neh. 2: 8). Similarly, the Church may identify the right time to embark on a fundraising project; however, it (still) needs to pray for divine wisdom and direction in addressing/embarking on the project. Aside from praying for the success of the project, the Church should also pray for the financial breakthroughs for the members as well as the grace to give generously in support of God's work.

One paramount issue in this type of relationship is the need for believers to give credit to the fountain of their life. Nehemiah did not attribute his success to his eloquence, expertise, or luck, he glorifies God for his success and this he acknowledged when he said, "the King granted them to me because the good hand of my God was on me" (Nehemiah 2: 8).

Additionally, patience is core to nurturing a vertical relationship. Whiles Nehemiah persisted in his fasting and prayers with the view of nurturing a relationship with God, he waited patiently upon the Lord for wisdom and direction before taking a step. In hearing about the devastating situation of his people, Nehemiah did not rash to the King and ask for permission to go and rebuild the broken walls nor did he make a hasty decision. He however concealed his burden and privately sought God's face until God finally provided the opportunity for him to talk to the King about his situation. Similarly, when he got to Jerusalem, he patiently waited for some days before implementing his motives. During the three days waiting period, he concealed his plans until the right time. ${ }^{14}$ In a similar vein, the Church may have a fundraising project at hand, nonetheless, it needs to wait patiently upon the Lord for wisdom and direction regarding when and how it should implement its project. Likewise, patience is paramount in the planning and implementation of fundraising activities. One may fast and pray for more than a week yet the expected result is not forthcoming. Like in the case of Daniel, one needs to persist in prayers (1 Thes. 5:16-18) and that is the surest way to maintain a healthy relationship with God. Sustaining, a healthy relationship with God requires constant communication with Him.

In addition, secret planning is vital in a vertical relationship. During the waiting period, Nehemiah did a lot of brainstorming and planning. Therefore, when the King asked him how long he was to be 'away', he gave a definite response. He did not only plan about the number of days he would spend in resolving the challenge but he also made a

\footnotetext{
11 Ken Burnett, Relationship fundraising: A donor-based approach to the business of raising money (2ed.), (San Francisco: Jossey-Bass 2002), 38: Penelope Burk, Donor-Centered Fundraising: How to hold on to your donors and raise more money, (Toronto: Cygnus Applied Research Inc. 2003).

2 Burnett, Relationship fundraising, 38.

3 Burnett, Relationship fundraising, 38.

14 Steven J. Cole, Lesson 2: The realities of serving God (Nehemiah 2:1-20). Accessed May 16, 2020.

https://bible.org/seriespage/lesson-2-realities-serving-god-nehemiah-21-20 (n. d.).
} 
definite request to the King (2:7-8). Nehemiah in this regard acted promptly; he responded quickly and efficiently to the King. Nehemiah's attitude indicates that he had been doing careful/thoughtful planning. His action implies he carefully thought of the vision of his fundraising. In other words, he carefully drew a mental picture of his vision in his heart and the role the King was supposed to play in the realisation of his rebuilding process. Nehemiah, after apportioning his projected needed resources to his prospective donors during his planning stage, did not waste time when the opportunity was presented to him to place his request before the King. In this regard, one can agree with Burnett that promptness is vital to building a fundraising relationship. ${ }^{15}$

Nehemiah further exhibited this thoughtfulness when he got to Jerusalem. In Jerusalem, he first assessed the situation of the broken walls and thoughtfully planned as to how to approach the project. In other words, Nehemiah had a well-structured vision as well as strategies or procedures he was going to use in reaching his goal. Similarly, in Ghana, most, if not all, churches plan before embarking on any fundraising project. In other words, the Church brainstorms and plans towards any fundraising projects she is to embark upon. Nonetheless, having a well-structured vision as well as strategies or procedures in reaching any fundraising goal is a challenge for some churches. Also, a paramount issue lacking in the planning stage, which is vital to any fundraising project, is the fundraising department. Here, the Church needs to have a fundraising department out of which a team should be picked and should be responsible for revenue generation for the Church. Additionally, the current system where members are given envelopes to solicit for funds from non-members (both Christians and Non-Christians) during harvest or appeal for funds should be relooked. For instance, members should be educated regarding the projected amount expected from each envelope given to nonmembers during the annual harvest. It is prudent to break the projected amount into the smallest cedi denominations where members are informed of the amount expected from each envelop given. This in a way can serve as a check on the bearers of the envelopes. The researcher has had similar envelops given to him and in most cases, he asked the bearers what they are expecting, in monetary terms, from him. The usual response received was 'whatever amount you have'. Such responses should be discouraged since it shows a lack of thoughtful planning. Responses of this nature imply that the Church or bearer has not carefully planned regarding what is expected of each donor and this is in contrast to the Nehemiah fundraising theology. Like Nehemiah, churches need to apportion their projected needed resources to their prospective donors during their planning stage(s). Additionally, they need not waste time when the opportunity is presented to them to place their request (envelopes) to non-members.

Related to this is that the donor needs to be made aware of the significant impact his/her donation would make in the realisation of a fundraising project. Here, the donor needs to be informed as to where he/she 'fits in' as well as made to identify himself or herself with the vision of the fundraising project. In other words, the donor needs to be helped to identify or see himself/herself as a part of a team or stakeholders who God intends to use to fulfil His mission on earth. The point is that donors need to identify themselves as well as know the 'part' they 'fill' in the fundraising or harvest programmes. This would make them know they are important, valued and considered and this has the effect of maximizing funds per donor as opined by Burnett. ${ }^{16}$ In addition, the donor needs to know that he/she can worship God with his/her finances. In this regard, giving is regarded as another form of worshipping God.

The researcher however shares Okyere's concern that Christians are living in an economy where hundreds of people find it difficult to subsist, hence, it is wise to allow prospective donors to decide the amount to give or put in an envelope meant for annual harvest or appeal for funds. ${ }^{17}$ The point is that faith and not worldly issues or challenges determine true (biblical) giving. A worthy illustration is the act of the Macedonian Christians who gave out of their afflictions (2 Cor. 8:1-5). Besides, every true Christian giving should be based on the theology of the Psalmist as indicated earlier. One may also argue that the above illustration and theology of the Psalmist do not apply to the nonbeliever; hence, the latter is not under any obligation or obliged to emulate the Macedonian Christians or the theology of the Psalmist. That is certainly true. One should however not forget the fact that the King, in Nehemiah's case, was not an Israelite and hence can be seen as a non-believer. Yet Nehemiah was able, through God, to make the King identify himself with Nehemiah's rebuilding vision. The King did not only give because Nehemiah told him the significant impact his contributions would make in the rebuilding process but perhaps saw his contribution bring psychological relief and security to a deprived nation. Additionally, he saw his donation bring joy and happiness to a nation that was demoralised. More importantly, basing the argument on the theology of the Psalmist, one can say that God 'engineered' the King's giving. In the same vein, God can 'move' non-believers to give to the Church. For instance, one can strongly believe that if a vision of a Church is to raise funds to provide portable water for a deprived community, some nonbelievers when approached by the Church would gladly assist, especially when the Church has evidence indicating that the same services have been undertaken earlier in other deprived communities. ${ }^{18}$ Besides, charitable giving is

\footnotetext{
15 Burnett, Relationship fundraising. 38.

16 Burnett, Relationship fundraising, 38

7 Excerpts of an interview held with Dr. Kojo Okyere, a Senior Lecturer with the Department of Religion and Human Values, University of Cape Coast.

This illustration is taken from the Maranatha Television, which is a product of the Maranatha Power Ministry, led by Bishop Francis Afotey Odai.
} 
encouraged by many, if not all religions of the world. The Church can, as it always does, appeal to non-believers for financial support when the need arises. Hence, it is paramount for the Church to seek God's face and guidance before embarking on any fundraising project. Praying for the financial breakthroughs as well as God's grace for donors to donate in support of God's work is also relevant in a vertical relationship.

\section{The Horizontal Relationship}

To work for God, the Church must learn to work with people, regardless of one's religious affiliation, and this requires establishing and nurturing a good relationship. Working with people needs sensitivity, tactfulness and prayer. Nehemiah was able to work with an unbeliever (the King) because of these features. Additionally, he gained the King's respect through his competence on the job. Aside from competency, he exhibited a trustworthy character and loyalty to his master, the King. These virtues are also significant in building a relationship. In this regard, every Christian should be a witness of Christ by godly character and competence and this will surely lead to the fostering of a good relationship as well as win non-believers to Christ.

In addition, Nehemiah was tactful in his communication with the King. Through his tactfulness, he was able to let the King identify with the vision of the fundraising project. To achieve this, he told a story to the King (Nehemiah 2: 1-3). In his narration, he appealed to the emotions of the King by telling his story with pace and passion. Nehemiah's pace and passion inspired as well as made the King identify himself with Nehemiah's vision. The King then asked, "for what do you make this request" (Neh. 2: 4a). With the King's identification, Nehemiah needed to identify where the King fitted in his vision. When this was accomplished, he then explained the significant role that the prospective donor (King) would play, through his contributions, in the realisation of the rebuilding vision. In 2: 7-8a, Nehemiah, in a clear and unambiguous language, presented a direct proposition to the King. Similarly, if the Church has a story to tell a donor, it can do that by making its story appeal to the emotions of the donor that will likely, with God's grace, inspire the donor to give. Other churches can emulate the illustration given above by the Maranatha Power Ministry. Such evidential stories coupled with the theology of the Psalmist will definitely 'move' some people, regardless of their religious affiliation, to donate generously to the ministry. It is important to note that the Church's story must be done in a clear and unambiguous language and indirect proposition so that donors can relate or identify with the intended fundraising project.

Another unique feature of a horizontal relationship is how to relate with the demoralized or needy people. Nehemiah had to deal with his fellow citizens who were demoralized because of slavery and the task of rebuilding the broken walls. According to Steven J. Cole, the Israelites believed in God and his covenant promises, nevertheless, regarding this predicament, they seemed to have lost hope. ${ }^{19}$ To deal with his demoralized people, Nehemiah had to be careful and secretive. He exhibited this when he got to Jerusalem. For three days, he carefully and secretly planned how to present his intended motive to the remnants of his people in Jerusalem. In the course of planning, he assessed the project privately (Neh. 2:11-16) and this was to have first-hand familiarity with the details of the task. ${ }^{20}$ The intention of doing his homework before seeking the support of the people was to have firsthand information regarding the rebuilding task as well as its associated challenges. With such background information, he was better armed to overcome the objections he anticipated from the people. After the groundwork, he met the Jewish leaders and people and placed his intention as well as the gravity of the situation before all (2:17). He knew he was dealing with a demoralized people, so he needed to be straight forward with them as well as needed a motivational message that would not only lift the remnant from their demoralized state, nevertheless would let them understand his vision and mission statements.

In this regard, his solicitation included a clear statement of the relevance of rebuilding the broken walls and testimony about God's favour, which was already evident in the project. ${ }^{21} \mathrm{He}$ even told them how God had worked through his master. His interaction with the remnant revived the hope of the people and this is evident when they said, "let us arise and build" (2: 18b). A people who were dead psychologically because of situational challenge(s) were revived by the wisdom and tact of a servant.

Comparably, to organise successful fundraising activities, the Church needs to share her goals with donors as well as have a motivational message that would not only uplift the spirits of congregants or donors who may be facing economic challenges. This would let them understand and appreciate God's favour that will be upon them should they donate in support of God's work.

After rekindling the hopes of the remnant, Nehemiah had to contend with challenges from the opposition. The opponents did all that they could to derail the divine vision of Nehemiah. ${ }^{22}$ Nonetheless, Nehemiah did not allow

\footnotetext{
19 Cole, "Lesson 2: The realities of serving God (Nehemiah 2:1-20)".

20 Marc A. Pitman, "Fund-raising in the Bible: Funding your mission doesn't mean losing your Soul". Accessed 15 April 2019. http: www.fund-raisingcoach.com.

21 Pitman, "Fund-raising in the Bible: Funding your mission doesn't mean losing your Soul."

22 Pitman, "Fund-raising in the Bible: Funding your mission doesn't mean losing your Soul."
} 
the strange storms from his opponents to derail his mission. He rode the storm triumphantly because he showed no fear of his opponents. He remained resolute to the cause of his divine assignment. More importantly, he rubbished his opponents by encouraging himself and his people by saying 'the God of heaven will prosper us' (2: 20a). This indicates that Nehemiah and his people trusted and depended on God to see them through in achieving the divine vision. In the same vein, the Church is likely to face opposition in its planning, organisation as well as in the implementation of its fundraising programmes. The opposition may surface in diverse forms and magnitudes. The Church, like in the case of Nehemiah needs to be resolute in its fundraising vision by encouraging itself in God's word. Thus, in fulfilling God's mission, the Church needs to work with people of all classes, race and religious affiliations. In achieving this, the Church must exhibit Christian values, which should led to the establishment and nurturing of a good relationship between the Church and the people. The good relationship couple with sharing the vision and mission of its fundraising projects in a clear and unambiguous language could motivate members as well as non-members to give in support of God's work. Of course, the challenges may surface in different proportions, but that should not derail the Church's fundraising plans. Like Nehemiah, the Church should keep trust and depend on God, who surmounts all challenges of the Church.

\section{Financial Stewardship in Fundraising Activities}

Regarding the administration of the funds, it can be deduced from the Nehemiah narrative that there were effective internal control mechanisms that ensured transparency and accountability, which is evident in the committee that was formed (3: 1-32). The committee was tasked with the custody and disbursement of the funds that were raised. The committee was given the mandate to freely operate within the parameters of financial management and accountability. Additionally, the committee was given the necessary support as well as the liberty to function without any hindrance or interference from any quarters. As trustees, they gave an account of their stewardship not only to their leader but also to their donors. In other words, the committee exhibited a spirit of accountability and transparency in the execution of their responsibilities. The effective communication link between the fundraisers and the committee served as a recipe for transparency and accountability.

This idea of transparency and accountability was made possible because the Israelites were conscious of the fact that their offerings were holy unto God. They saw the funds raised as sacred revenue and hence using it to glorify their God was of paramount concern to them. Even the offering bowl and the place where the offerings were made were all considered as sacred. Hence, the Israelites were conscious of treading on sacred ground when raising funds and even those responsible for the safekeeping as well as disbursement of such funds were conscious of handling sacred funds. ${ }^{23}$ The issue of transparency and accountability is still a challenge to most churches in the country. Additionally, concerning the sacredness of the generated funds, offering bowls as well as the offering place, the Israelites' attitude towards things related to giving seems missing in most, if not all, Ghanaian churches. This is partially contributing to the incidence of embezzlement of church funds by some Christians. This, to some extent, has demoralised some believers not to give or donate generously to the Church.

\section{CONCLUSION}

The Ghanaian Church has depended on the traditional system of soliciting for funds since its inception. Even in this twenty-first century where the Ghanaian Church has become sophisticated, it still depends mainly on the traditional system of soliciting for funds. The sophistication of the Church has led to a modification of the liturgical practices of the Church and one affected aspect is fundraising. The modification has further led to the introduction of several fundraising strategies, some of which are allegedly unbiblical.

Additionally, the overdependence on the traditional system has led to fatigue in giving. Perhaps, envisaging the consequences of the fatigue in giving is why some prominent personalities have decided to call on the Church to wean itself from the traditional system and be receptive to alternative sources of funding. The fact is that the overdependence of the Church on the traditional system of funding is never healthy and this is because the Church's capacity to fulfil its core divine mission may dramatically be impeded especially now that some Christians are experiencing fatigue regarding giving. This is likely to have an adverse effect or hinder mission, evangelism and Church growth and personal spirituality. This paper sees Nehemiah's fundraising model as a viable alternative to the Church to wean itself from the traditional system of fundraising in the Church. The application of Nehemiah's fundraising model would aid the Church not only to generate more funds to meet its ever-increasing demands; it would also lead the Church to serve God realistically. This paper, therefore, advocates for the diversification of the sources of soliciting funds for the Church to off-load the overdependence on the congregants as well as become survivors in a competitive global economy.

\footnotetext{
23 Ray Mayhew, 'Embezzlement: The corporate sin of contemporary Christianity?' Accessed 16 June 2018. https://dashhouse.com/wpcontent/uploads/2005/06/EmbezzlementPaper.pdf.
} 


\section{ABOUT AUTHOR}

Iddrissu A. Shaibu (PhD), a lecturer with the Department of Religion and Human Values, College of Humanities and Legal Studies, University of Cape Coast, Cape Coast- Ghana, received his MPhil and Ph.D. from the University of Cape Coast, Ghana. He joined the department in 2005 as a teaching assistant and through a dint of hard work became a lecturer at the department in 2012 to date. He teaches in the area of Church and Society and his major research interest centers around Early Church history, Church and finance and New Religious Movements. E-mail: isadam@ucc.edu.gh

\section{BIBLIOGRAPHY}

Andreasen, R. Alan and Kotler, Philip. Strategic marketing for nonprofit organizations, Prentice-Hall, Upper Saddle River, NJ. 2008.

Beckmann, M. David. Eden revival spiritual churches in Ghana. London:Concord Publican House, 1975.

Burk, Penelope. Donor-Centered Fundraising: How to hold on to your donors and raise more money. Toronto: Cygnus Applied Research Inc. 2003.

Burnett, Ken. Relationship fundraising: A donor-based approach to the business of raising money (2ed.). San Francisco: Jossey-Bass.2002.

Ghanaian Times, 'Presby Moderator: Church offerings are too much,' 8 August 2010. Accessed 15 May 2020. https://www.modernghana.com/news/288574/presby-moderator-church-offerings-are-too-much.html

Kelly S. Kathleen. Effective fund- raising management. Mahwah, NJ: Erlbaum. 1998.

Klein, Kim. Fundraising for social change. San Francisco: Jossey-Bass. 2007.

Kunhiyop, W. Samuel. African Christian ethics. Nairobi: Hippo Books 2008.

Marc, A. Pitman. (n. d.). Fund-raising in the Bible: Funding your mission doesn't mean losing your Soul. Accessed 15 April 2019. http://www.fund-raisingcoach.com

Mayhew Ray. 'Embezzlement: The corporate sin of contemporary Christianity?' https://ashhouse.com/wpcontent/uploads/2005/06/EmbezzlementPaper.pdf

News Ghana, "Local churches told to wean itself from the traditional sources of generating funds."March 2014. Accessed 15 May 2020.

https://newsghana.com.gh/local-churches-told-to-wean-itself-from-the-traditional-sources-of-generatingfunds $/ 9$

Shaibu, A. Iddrissu. "Approaches to Church Fundraising and their Implications for Christians in Ghana: Case studies of selected Churches in Cape Coast". A PhD thesis submitted to the Dept. of Religion and Human Values, University of Cape Coast-Cape Coast, 2010.

Steven J. Cole. "Lesson two: The realities in serving God". Accessed on 2 May 2020. https://bible.org/seriespage/lesson-2-realities-serving-god-nehemiah-21-20.(2002)

Turner, W. Harry. History of an African independent church, Vol. 2. (London: Clarendon Press, 1967).

Wilson, R. Kent. Stewards'leadership: Characteristics of the steward leader in Christian non-profit organisations. Scotland: University of Aberdeen. 2010. 